\title{
Ulisses e o Canto Das Sereias: Sobre Ativismos Judiciais e os Perigos da Instauração de um "Terceiro Turno da Constituinte"
}

\author{
Lenio Luiz, Streck \\ Vicente De Paulo Barretto \\ Rafael Tomaz De Oliveira
}

\section{RESUMO}

Nos últimos anos, o direito brasileiro foi tomado por uma nau teórica que admite e defende a necessidade de ativismos judiciais para resolver problemas políticos e sociais apresentados pelo cotidiano. A última tentativa encampada neste sentido manifestou-se através da Argüição de Descumprimento de Preceito Fundamental (ADPF) n. 178, proposta pela Procuradoria Geral da República com intuito de regulamentar a união entre pessoas do mesmo sexo. No presente artigo, pretendemos problematizar essa questão, demonstrando como que, embora fundada em boas intenções, tal medida representaria grave risco democrático, pois transformaria a jurisdição constitucional em verdadeiro poder constituinte permanente.

\begin{abstract}
Ulysses And The Sirens: About Judicial Activisms And The Dangers Of Creating A "New Constitutional Convention" By The Judicial Power

In the last years, the Brazilian Law has been taken by a great amount of theory that admits and defends the need for judicial activism to solve daily political and social problems. The last temptation in this sense was made through the Breach Claim of Fundamental Precept n. 178 proposed by the Attorney's General Office with the intention of regulate the union of people with same sex. On this present article, we intend to discuss this issue, demonstrating that although founded on good intentions such measure would represent a serious democratic risk because it would transform the constitutional jurisdiction into a truly permanent constituent power.
\end{abstract}

Keywords: judicial activism, homoaffective unions, constitutional jurisdiction

\section{Notas Introdutórias: Ulisses Acorrentado - A Constituição Como Pré-Compromisso}

Há uma obra de Otto Bachof que é bastante conhecida pelos cultores do direito constitucional. Ela se chama Normas Constitucionais Inconstitucionais? (BACHOF, 1994). A grande ironia que existe por trás desse fato notório é que o conhecimento das motivações históricas que levaram o professor alemão a escrevê-la é inversamente proporcional ao seu sucesso e a sua “popularidade”. Talvez seja interessante lembrá-los aqui. Principalmente quando vivemos em um país em que, a todo tempo, setores do pensamento jurídico-político apresentam teses que têm como pretexto um problema particular do cotidiano para, no fundo, desconstituir a Constituição (sem falar na patética tentativa recentíssima da PEC 341/09 que pretende cometer um haraquiri institucional, reduzindo a Constituição a 70 artigos). Essas 
propostas vão desde mini-constituintes para efetuar uma duvidosa reforma política, até à construção de um ambiente doutrinário no interior do qual se convive pacificamente com a degradação dos (pré)compromissos estabelecidos pelo constituinte de 1988 através de uma irresponsável defesa de bons ativismos judiciais para resolver problemas que a realidade imediata apresenta.

Desconsidera-se, assim, o elán vital que imprime significado a uma Constituição: ela é feita em momentos de "sobriedade" política para defender o Estado e a sociedade exatamente destas erupções episódicas de paixões e desejos momentâneos. Algo que pode ser compreendido a partir de Homero e seu Ulisses. Como é sabido, na Odisséia, Ulisses, durante seu regresso a Ítaca, sabia que enfrentaria provações de toda sorte. A mais conhecida destas provações era o "canto das sereias" que, por seu efeito encantador, desviava os homens de seus objetivos e os conduzia a caminhos tortuosos, dos quais dificilmente seria possível retornar. Ocorre que, sabedor do efeito encantador do canto das sereias, Ulisses ordena aos seus subordinados que o acorrentem ao mastro do navio e que, em hipótese alguma, obedeçam qualquer ordem de soltura que ele pudesse vir a emitir posteriormente. Ou seja, Ulisses sabia que não resistiria e, por isso, criou uma auto-restrição para não sucumbir depois.

Do mesmo modo, as Constituições funcionam como as correntes de Ulisses, através das quais o corpo político estabelece algumas restrições para não sucumbir ao despotismo das futuras maiorias (parlamentares ou monocráticas). Isso é de fundamental importância. Algo que os gregos ainda podem nos ensinar com a autoridade daqueles que forjaram o discurso democrático: entre eles as decisões mais importantes acerca dos destinos da pólis só poderiam ser levadas a efeito no diálogo que se estabelecia na ágora.

Mesmo nos momentos de desespero coletivo - como ocorre em casos de Guerra, o que aparece claramente no texto de Homero - era necessário obedecer à razão e não às paixões temporárias ou aos interesses derivados das preferências pessoais de cada um dos indivíduos. Como Ulisses e suas correntes, também a democracia construída pelos gregos passava pelo desenvolvimento de mecanismos que limitavam o exercício do poder e o racionalizavam. Enfim, mecanismos de pré-compromissos, ou de auto-restrição...

\section{Repristinação De Duas Velhas Teses: A Possibilidade De Normas Constitucionais Inconstitucionais E A Instauração De Uma Jurisprudência Dos Valores}

No caso de Bachof, o problema era de outra magnitude. Com efeito, nos anos que sucederam a outorga da Lei Fundamental (Grundgesetz) de Bonn (1949), a cultura jurídica 
alemã produziu um amplo debate sobre as questões que estavam implicadas neste ato. Essa Carta, produzida sob os auspícios do governo de transição instalado pelos aliados, não poderia ser chamada de Constituição (Verfassung) porque lhe faltava o elemento de legitimação popular: não foi o povo alemão que colocou as regras que nela se apresentavam. Diante disso, a tese de Bachof pode ser enquadrada diante da seguinte pergunta: haveria a possibilidade de dizer que normas constitucionais possam ser inconstitucionais, por contrariar algum tipo de essência jurídica absoluta, ou mesmo o próprio sistema interno do texto constitucional, de modo a permitir uma alteração significativa de seu conteúdo? Quer dizer: tratava-se da (tentativa de) afirmação de um direito para além da própria lei fundamental que permitisse algo como uma "Constituição verdadeiramente alemã” (cf. BACHOF, 1994).

Por certo - e todos sabemos disso -, a tese de Bachof não vingou. Ao contrário, o Tribunal Constitucional Federal (Bundesverfassungsgericht) acabou se tornando o grande responsável pela legitimação da Lei Fundamental num período que ficou conhecido como jurisprudência dos valores (com todas as críticas que a ela devem ser feitas) (cf. LARENZ, 1997). Há autores que consideram que foi nessa época em que se deu a "perda das certezas jurídicas", referindo-se ao fato da criação de instrumentos metodológicos que propiciaram a "abertura" da estrita legalidade que sempre imperou em território germânico (cf. LAMEGO, 1999, p. 80 e seg.; OLIVEIRA, 2008, p. 57 e seg.). Em sentido próximo, colocando com precisão os problemas que surgem em torno da interpretação da Constituição, também Vicente Barretto aponta para as dificuldades de se encontrar uma teoria da interpretação jurídica no contexto desse movimento provocado pelo aparecimento das novas constituições que fundaram o Estado Democrático de Direito (cf. BARRETTO, 1999). Momento esse que possibilitou a criação e redefinição de uma série de institutos jurídicos como é o caso das chamadas "cláusulas gerais", dos "conceitos jurídicos indeterminados", das "normas em branco" e, evidentemente, dos chamados "princípios constitucionais".

São nestes dois âmbitos de análise que tomamos emprestado o título da obra de Bachof para refletir sobre uma questão que tem tomado força em nossa comunidade jurídica. Trata-se da (tentativa de) regulamentação de uniões homoafetivas via jurisprudência do STF, como se fosse possível fazer um "terceiro turno" no processo constituinte. Com efeito, na teia de argumentos que se apresentam para a efetuação de uma tal medida, estão cruzados os dois modelos teóricos retratados acima. Eles se articulam de dois modos:

a) explicitamente, porque há uma tentativa de instauração de uma verdadeira jurisprudência da valoração, na medida em que se pretende criar uma "abertura de espaços jurídicos" para a criação de algo que depende da regulamentação do poder legislativo; 
b) implicitamente, porque a argumentação da Procuradoria Geral da República leva à repristinação da idéia superada de que poderia haver normas constitucionais inconstitucionais, na medida em que o próprio $\S 3^{\circ}$ do art. 226 da Constituição Federal seria inconstitucional (sic!) ao declarar que a proteção do Estado se destina a união entre o homem e a mulher, contrariando assim princípios sensíveis da Constituição como é o caso da segurança jurídica e da dignidade da pessoa humana.

O que preocupa neste tipo de pedido de tutela judicial é que ele traz consigo - de modo subterrâneo - uma idéia que tem ganhado terreno e aceitação por parte da dogmática jurídica nacional: a necessidade de se recorrer a "bons ativismos judiciais" para resolver questões que a sociedade em constante evolução acarreta e que os meios políticos de decisão (mormente o legislativo) não conseguem acompanhar.

Ora, as experiências históricas que nos foram legadas e que permitem desenvolver um conceito de ativismo judicial não apontam para o "bem" ou para o "mal" das atividades desenvolvidas sob este signo. Certamente, o que temos de modo substancial sobre o tema são as experiências oriundas dos Estados Unidos e da Alemanha. No contexto norteamericano, como nos lembra Christopher Wolfe, em seu The rise of modern Judicial Review, o ativismo judicial pôde nomear desde as posturas conservadoras que perpetuaram a segregação racial e impediram as transformações econômicas que o new deal de Roosevelt tentava operar na primeira metade do século 20, até as posturas tidas como progressistas ou liberais da Corte de Warren na década de 1960 (cf. WOLFE, 1994).

Na Alemanha, como já afirmamos, a atividade do Tribunal Constitucional Federal também chegou a ser classificada por alguns autores como ativismo judicial, originando a corrente chamada jurisprudência dos valores (de se ressaltar que é exatamente a jurisprudência da valoração que será duramente criticada por Habermas, que a enquadrará como uma postura do poder judiciário que coloniza o espaço público e impede a tomada de decisões pela via democrática).

Em todos estes casos, o mais correto é dizer que não há como determinar a "bondade" ou a "maldade" de um determinado ativismo judicial. O mais correto é dizer que questões como essa que estamos analisando não devem ser deixadas para serem resolvidas pela “vontade de poder" (Wille zur Macht) do Poder Judiciário. Delegar tais questões ao Judiciário é correr um sério risco: o de fragilizar a produção democrática do direito, cerne da democracia (STRECK, 2009). Ou vamos admitir que o direito - produzido democraticamente - possa vir a ser corrigido por argumentações teleológicas-fáticas-e/ou-morais? 


\section{Casuística: Os Motivos Da (Im)Possibilidade Da Adpf N. 178}

Vejamos, resumidamente, como a questão está colocada nos termos da ADPF n. 178. Tal medida foi interposta no dia 02.07.2009 pela Procuradoria Geral da República, mediante representação do Grupo de Trabalho de Direitos Sexuais e Reprodutivos da Procuradoria Federal dos Direitos do Cidadão, objetivando o reconhecimento de união estável entre pessoas do mesmo sexo e a garantia dos mesmos direitos dos companheiros heterossexuais.

Cumpre salientar que, em virtude de despacho exarado pelo presidente do Pretório Excelso, a Procuradoria Geral da República emendou o pedido inicial no sentido de transformar a ADPF em verdadeira ADI, que teria como objeto o art. 1723 do Código Civil. Isso se deu em virtude de - nos termos do mencionado despacho - existir um problema formal no pedido formulado pela Procuradoria: a "inexistência aparente de objeto específico e delimitado" a ser enfrentado pela medida proposta. Ou seja, o pedido inicial não informava qual ato deveria ser desconstituído ou sequer que tipo de ação o Estado estava desenvolvendo no sentido de descumprir os princípios sensíveis da Constituição.

Na petição aditiva, a PGR aduziu que os atos do poder público, objetos da ação, eram dois:

a) Primeiro, o não reconhecimento pelo Estado Brasileiro das uniões homoafetivas. Tal fato importaria em uma omissão (sic) e que, por isso, não seria possível indicar os atos concretos específicos que ensejariam a procedência do pedido.

Neste ponto, ainda há uma questão que precisa ser enfrentada: qual a diferença entre essa omissão alegada pela PGR e a omissão inconstitucional que deve ser corrigida pela via do Mandado de Injunção ou pela Ação Direita de Inconstitucionalidade por Omissão? Nos termos do pedido a diferença é marcada pelo fato de o Estado brasileiro já se encontrar obrigado (sic) a reconhecer as uniões homoafetivas independentemente da edição de qualquer norma infraconstitucional, em face da aplicabilidade imediata das normas de direitos fundamentais.

Ora, se aceitarmos esse tipo de argumento, continuaríamos dando vigência à vetusta tese daquilo que se convencionou a chamar de Direito Constitucional da Efetividade que insiste em dividir o texto da Constituição ao modo da metafísica essencialista, entre normas constitucionais programáticas e não-programáticas (como se fosse possível atribuir normas aos textos sem que uma situação concreta fosse ao menos vislumbrada pelo intérprete!?!) o que seria um duro golpe na idéia já sedimentada na doutrina constitucional de força normativa da Constituição. 
E mais: de que modo poderia haver a referida omissão se a própria Constituição determina que é dever do Estado proteger a união entre o homem e a mulher? Onde estaria a omissão, já que é um comando constitucional - e note-se: não podemos falar em hierarquia entre normas constitucionais, caso contrário, estaríamos aceitando a tese de Bachof a respeito da possibilidade de existência de normas constitucionais inconstitucionais - que determina que a ação do Estado seja no sentido de proteger a união entre homem e mulher?

b) O segundo objeto da medida seriam as várias decisões judiciais que vem dando interpretação restritiva (sic) ao art. 1723 do CC, interpretando, assim, a Constituição de forma equivocada (sic).

Vejamos: nos termos da tese defendida pela PGR, a interpretação correta da Constituição aponta para um contexto mais amplo do que aquele retratado no mencionado artigo. A principiologia constitucional (mesmo com o $\S 3^{\circ}$ do art. 226 dizendo explicitamente - o contrário) apontaria para a necessidade de compreender que a proteção do Estado à união estável entre homem e mulher deveria ser estendida às relações homoafetivas. A expressão homem e mulher contida no texto constitucional seria meramente exemplificativa (sic!). In verbis, a posição da PGR:

\footnotetext{
A única interpretação que torna o preceito (art. 1723 CC acrescentamos) compatível com a Lei Maior é a que concebe a expressão 'homem e mulher', contida em seu texto, como meramente exemplificativa, de forma a admitir a interpretação analógica do dispositivo, para que ele se estenda à união entre pessoas do mesmo sexo, desde que se configure como convivência pública, contínua e duradoura, estabelecida com objetivo de constituição de família.
}

Desse modo, a PGR pugna, como pedido subsidiário, pela transformação da ADPF em ADI com pedido de Interpretação Conforme do art. 1723 do $\mathrm{CC}$, de modo que ele apenas seria compatível com a Constituição se lido ao modo retratado acima.

De plano, salta aos olhos a seguinte questão: a efetivação de uma medida desse jaez importa(ria) transformar o Tribunal em um órgão com poderes permanentes de alteração da Constituição, estando a afirmar uma espécie caduca de mutação constitucional (Verfassungswandlung) que funcionaria, na verdade, como um verdadeiro processo de alteração formal da Constituição (Verfassungsänderung), reservado ao espaço do Poder Constituinte derivado pela via do processo de emenda constitucional.

E isso porque a tese da PGR se perde em meio ao problema semântico e não avança em direção ao fenômeno mesmo que é a applicatio do texto constitucional. Essa hipertrofia com relação à semântica (que não deixa de ser um sintoma da permanência das bases 
positivistas no seio da dogmática constitucional) - que aparece claro em expressões como "interpretação restritiva" ou "extensiva" - encobre o problema essencial: como dar efeito vinculante e eficácia erga omnes a uma decisão do Supremo Tribunal Federal que realize uma Interpretação Conforme a Constituição (verfassungskonforme Auslegung)? Poder-se aduzir que o parágrafo único do art. 28 da lei n. 9868/99 autoriza tais efeitos para decisões que se utilizem das chamadas sentenças interpretativas lato senso. Mas, mesmo aqui, caberia o questionamento: poderia a lei ordinária alargar o espaço já estabelecido pelo poder constituinte? Não haveria, na espécie, usurpação de competência do constituinte? Vingando a tese, teríamos algo inusitado: quando nem a lei ordinária e nem a Constituição explicitam um determinado direito, "faz-se" uma interpretação conforme..., embora não se indique de que forma ocorre a incidência da parametricidade do texto constitucional.

E mais. As sentenças interpretativas só podem ser corretamente compreendidas através da diferença (ontológica - ontologische Differenz) que existe entre texto e norma. A interpretação conforme a Constituição não modifica o texto da norma, mas produz uma norma a partir da parametricidade constitucional. Esse é o limite do sentido e o sentido do limite. $\mathrm{Ou}$ seja, somente a partir dela - da parametricidade constitucional - e não a partir de analogias ou outras formas de extensão de sentido, é que se pode fazer a referida atribuição de sentido (Sinngebung). E, outra coisa: a diferença entre texto e norma não quer dizer que seja permitida a atribuição de qualquer norma ao texto (STRECK, 2008). E muito se pode admitir que, a pretexto da aplicação da máxima hermenêutica "texto e norma", a PGR venha a pretender substituir o próprio texto da Constituição - pela via indireta da interpretação conforme dada ao Código Civil - por um outro (aquele que ela, a PGR, entenda ser mais adequado).

Portanto, voltamos ao problema fundamental da questão que passa ao largo das discussões jurídicas empreendidas nessa seara. Ou seja, que tipo de democracia queremos? Não se trata de ser contra ou a favor da proteção dos direitos pessoais e patrimoniais dos homossexuais. Aliás, se for para enveredar por esse tipo de discussão, advertimos desde já que somos absolutamente a favor da regulamentação de tais direitos, desde que efetuados pela via correta, que é a do processo legislativo previsto pela Constituição Federal.

O risco que exsurge desse tipo de ação é que uma intervenção desta monta do Poder Judiciário no seio da sociedade produz graves efeitos colaterais. Quer dizer: há problemas que simplesmente não podem ser resolvidos pela via de uma idéia errônea de ativismo judicial. O Judiciário não pode substituir o legislador (não esqueçamos, aqui, a diferença entre 
ativismo e judicialização: o primeiro, fragilizador da autonomia do direito; o segundo, contingencial).

Explicando melhor: em um regime democrático, como bem afirma Ronald Dworkin, em seu A Virtude Soberana, é preciso fazer uma distinção entre preferências pessoais e questões de foro de princípio. O judiciário pode intervir - e deve - sempre que estiver em jogo uma questão de princípio. Mas não cabe a este poder exarar decisões que manifestem preferências pessoais de seus membros ou de uma parcela da sociedade (cf. DWORKIN, 2002; DWORKIN, 2006b). Isso por um motivo bastante simples: a democracia é algo muito importante para ficar à mercê do gosto pessoal dos representantes do Poder Judiciário. Se assim fosse, os próprios interesses dos homossexuais estariam em risco, posto que a regulamentação das relações entre pessoas do mesmo sexo dependeria da "opinião" e da "vontade" daquele que julga a causa.

Imaginemos: se a questão é analisada por um magistrado favorável ao movimentos das minorias e da regulamentação de tais relações, sua decisão seria no sentido da procedência; por outro lado, um magistrado conservador e alheio a essa "mutação dos costumes" julgaria improcedente o pedido. E é isso que, num caso como esse, não pode acontecer! A decisão a ser tomada em tais casos precisa ser levada a cabo no espaço político, e não no jurisdicional, justamente para evitar que sua resolução fique à mercê das opiniões pessoais dos ministros da Corte Constitucional. Ou seja, a decisão deve ser construída no contexto de uma sociedade dialogal, em que o Poder Judiciário tem sua função que não consiste em legislar. Em suma, uma questão como essa, justamente pela importância da qual está revestida, não pode ser resolvida por determinação de um Tribunal. É necessário que haja uma discussão mais ampla, que envolva todos os seguimentos da sociedade, cujo locus adequado encontra-se demarcado nos meios democráticos de decisão.

De todo modo, há uma perigosa tendência no interior da comunidade jurídica de recorrer aos tribunais para sanar eventuais omissões do legislador, pugnando por um verdadeiro exercício de uma tardia jurisprudência dos valores pelo STF (ou pelos demais tribunais da República). Sem esquecer que, por vezes, o fato de o constituinte não tratar do assunto não possa significar “omissão"...; pode ser, na verdade, uma escolha política. Basta notar que a atual ADPF (ou será ADIn? Ou poderia ser as duas coisas ao mesmo tempo?!?) foi distribuída por dependência a ADPF n. ${ }^{\circ}$ 132, que já havia sido ajuizada pelo Governador do Estado do Rio de Janeiro. As razões de ambas estão fundadas em uma alegada violação de princípios constitucionais (lesão a direito) e nas freqüentes denegações de direitos aos homossexuais. Tudo isso porque a união entre pessoas do mesmo sexo é uma "realidade fática 
inegável", fruto do processo de "liberalização dos costumes", já reconhecida em outros países, sendo que a ausência de tratamento "com mesmo respeito e consideração" em relação às uniões estáveis entre pessoas de sexos diferentes representa um "menosprezo à identidade e à dignidade" dos homossexuais. Trata-se da assunção de um sociologismo com roupagens jurídicas, mais do que argumentos que tratem de valores éticos e sua regulação jurídica. A ação menciona, ainda, a violação aos seguintes princípios constitucionais: 1) da dignidade da pessoa humana, 2) da igualdade, 3) da vedação de discriminações odiosas, 4) da liberdade e 5) da proteção da segurança jurídica.

Não deixa de ser instigante o fato de se mencionar o princípio da segurança jurídica como argumento autorizador da medida ajuizada pela Procuradoria Geral da República, uma vez que a procedência da ação poderia gerar uma instabilidade institucional pela fissura provocada no texto da Constituição através de um protagonismo da Corte Constitucional. Afinal, qual é o limite da jursdição constitucional? Se nem uma mínima entificação (semanticidade) funciona como limite, o que impede de o STF alterar "qualquer preceito constitucional"? Em outras palavras, a (in)segurança jurídica mostra-se ofendida, não por deixar sem regulamentação legal a convivência entre pessoas do mesmo sexo, mas, sim, no momento em que a Corte altera, a pretexto de um "esquecimento do constituinte" (sic) ou de uma "descoberta valorativa" (sic), ou, ainda, do saneamento (incorreto) de uma “inconstitucionalidade da própria Constituição" (sic), o texto da Constituição como se Poder constituinte fosse, gerando um tipo de mal-estar institucional gravíssimo.

Importante salientar, ainda, que a própria utilização da ADPF como mecanismo apto a sanar a "omissão do legislador" (sic) é equivocado. Isso porque, em casos de efetiva omissão, o manejo adequado dos mecanismos de jurisdição constitucional aponta para a propositura de um mandado de injunção (art. $5^{\circ}$, LXXI da CF). Ora, o mandado de injunção é ação de efeitos concretos que manteria o equilíbrio institucional entre os poderes da república, enquanto que a ADPF, pela sistemática dos efeitos da decisão, faz com que o judiciário haja como se legislador fosse, criando efetivamente, uma regra geral e abstrata. Sem contar que, neste caso, a atuação do judiciário não atingiria simplesmente a atuação do legislador ordinário, mas provocaria um rompimento com a própria ordem constitucional, alterando formalmente $\mathrm{o}$ texto do $\S 3^{\circ}$ do art. 226. De todo modo, mesmo o mandamus injuntivo não teria espaço constitucional, pelo simples fato de que o texto constitucional aponta para o contrário da pretensão. Ou seja, não é possível superar o limite do texto: levemos o texto (constitucional) a sério. 
E note-se que a questão do reconhecimento da união estável entre pessoas do mesmo sexo já vinha sendo discutida judicialmente, existindo decisões de primeira e segunda instâncias sobre o assunto. Também nestes casos houve um nítido excesso do poder judiciário no sentido de romper com o texto da Constituição. Isso é um sintoma daquilo que aqui estamos chamando de "repristinação da jurisprudência dos valores". Ora, sob pretexto e a despeito do texto da Constituição propiciar um tecido normativo "fechado" demais, setores do direito pensam que é preciso "abrir" esse sentido da normatividade constitucional com um uso aleatório e descompromissado dos princípios constitucionais. Princípios estes invocados a partir de uma espécie de "anemia significativa", na qual a grande revolução operada pelo neoconstitucionalismo - os princípios representam a inserção do mundo prático no direito acaba por ser obnubilada por algo que se pode denominar panprincipiologismo. (cf. STRECK, 2009).

O seguinte acórdão, originário do TJRS - com fundamentação similar a outras decisões oriundas do Tribunal Regional Federal da $4_{-}^{\mathrm{a}}$ Região -, bem demonstra essa espécie de retorno (tardio) a uma jurisprudência de valores ou, se se quiser, a uma espécie de positivismo fático. Com efeito, enquanto a Constituição do Brasil estabelece que "para efeito da proteção do Estado, é reconhecida a união estável entre o homem e a mulher como entidade familiar, devendo a lei facilitar sua conversão em casamento" (art. 226, § $3^{\circ}$ ), o Tribunal gaúcho "colmatou" uma "omissão do constituinte" (sic), verbis:

\footnotetext{
União estável homoafetiva. Direito sucessório. Analogia. Incontrovertida a convivência duradoura entre parceiros do mesmo sexo, impositivo que seja reconhecida a existência de uma união estável, assegurando ao companheiro sobrevivente a totalidade do acervo hereditário, afastada a declaração de vacância da herança. A omissão do constituinte e do legislador em reconhecer efeitos jurídicos às uniões homoafetivas impõe que a Justiça colmate a lacuna legal fazendo o uso da analogia. $\mathrm{O}$ elo afetivo que identifica as entidades familiares impõe seja feita analogia com a união estável, que se encontra devidamente regulamentada (STRECK, 2009, p. 213-214).
}

Antes de tudo, apenas registremos: é a Constituição (que não pode ser inconstitucional) que diz "união estável entre o homem e a mulher como entidade familiar, devendo a lei facilitar a sua conversão em casamento"...! O que a lei deve facilitar é a conversão em casamento dessa relação entre homem e mulher...! É por isso que, em um Estado Democrático de Direito, mesmo que sejamos todos a favor de uma causa, é necessário esperar pelo legislador...! Aliás, como bem diz Dworkin, não deve importar ao direito o que os juízes pensam sobre o direito, sobre a política, futebol, etc. Aplicar o direito quer dizer 
"fazer interpretação com base em argumentos de princípio", e não "por argumentos pessoais", etc. Portanto, quando se pergunta ao judiciário sobre alguma coisa, este não pode responder com argumentos pessoais, políticos, morais, etc. Em uma democracia não se quer saber o que o juiz pensa sobre determinada fenômeno; o que ser quer saber é como se pode alcançar uma resposta a partir do direito. E, definitivamente, o direito não é - e não pode ser - aquilo que o judiciário "diz que é”!

Reafirmando o que já foi mencionado acima: não cabe ao Poder Judiciário "colmatar lacunas" (sic) do constituinte (nem originário e nem derivado). Ao permitir decisões desse jaez, estar-se-á incentivando a que o Judiciário "crie" uma Constituição "paralela" (uma verdadeira "Constituição do B"), estabelecendo, a partir da subjetividade dos juízes, aquilo que "indevidamente" - a critério do intérprete - não constou no pacto constituinte. O constituinte não resolveu? "Chame-se o Judiciário...." Ou "criemos um princípio", que "valerá" mais do que a Constituição...!

Ora, é necessário ter coragem para dizer algumas coisas, mesmo que possam parecer "antipáticas" aos olhos da comunidade jurídica. A resolução das querelas relativas às uniões homoafetivas deve ser feita - enquanto não for emendada a Constituição ou elaborada lei ordinária (a exemplo do que ocorréu, p.ex., na Espanha) - no âmbito do direito das obrigações, e não a partir do direito sucessório ou do direito de família. Há limites hermenêuticos para que o Judiciário se transforme em legislador.

Veja-se que um dos argumentos utilizados - ao menos no plano retórico para justificar as referidas decisões - é o de que o Judiciário deve assegurar a união estável (portanto, equiparação ao casamento) de casais homossexuais porque o Legislativo não pretende, a curto prazo, por não dispor de “condições políticas” para tal, elaborar legislação a respeito. Mas, convenhamos, é exatamente esse argumento que se contrapõe à própria tese: em uma democracia representativa, cabe ao Legislativo elaborar as leis (ou emendas constitucionais). $\mathrm{O}$ fato de o Judiciário - via justiça constitucional - efetuar "correções" à legislação (filtragem hermenêutico-constitucional e controle stricto sensu de constitucionalidade) não significa que possa, nos casos em que a própria Constituição aponta para outra direção, construir decisões "legiferantes".

Dito de outro modo: a Constituição reconhece união estável entre homem e mulher, mas isso não significa que, por não proibir que essa união estável possa ser feita entre pessoas do mesmo sexo, a própria Constituição possa ser "colmatada", com um argumento kelseniano do tipo "o que não é proibido é permitido" (sic!). Fosse assim e inúmeras não proibições poderiam ser transformadas em permissões: por exemplo, a Constituição de 1988 também 
não proíbe ação direta de inconstitucionalidade de leis municipais face à Constituição Federal (o art. 102, I, "a", refere apenas a possibilidade de argüição que trate de leis federais e estaduais). E nem por isso torna-se possível falar em ADIn contra lei municipal em sede de STF. Veja-se: em nome do "princípio democrático" ou da "república", os munícipes espalhados pelos quatro cantos do Brasil poderiam alegar que "a Constituição originária violou o princípio da isonomia e que a falta de um mecanismo desse quilate viola direitos fundamentais", etc. Ora, nada disso pode ser "colmatado" por um ato voluntarista do Judiciário (veja-se que a ADPF acabou resolvendo o problema - por lei -, ao admitir-se o sindicamento de leis municipais em face da Constituição sempre que não houver outro modo de solucionar a querela; mas, insista-se: foi por via legislativa a alteração do estado da arte) (STRECK, 2009, p. 213214). E o que dizer da "discriminação" entre homem e mulher para os casos de aposentadoria? Se homens e mulheres devem ser iguais, por que as mulheres se aposentam mais cedo? Não seria o caso de ingressar com uma ADPF para substituir a expressão homens e mulheres por "indivíduos”? E assim por diante...!

Ainda para exemplificar: a legislação civil trata apenas da alteração do prenome. Isso não significa, entretanto, a partir da máxima “o que não é proibido é permitido", que o Judiciário possa determinar a alteração do apelido de família, na hipótese de alguém se sentir humilhado pelo sobrenome que carrega, alegando, v.g., o princípio da dignidade da pessoa humana. E, registre-se: o princípio da dignidade da pessoa humana não pode ser panacéia para todos os males, mormente de "omissões" (sic) do constituinte: o direito possui um mínimo de objetividade, que é o texto. E em se tratando do texto da Constituição, assume maior relevância a máxima de que “devemos levar o texto a sério". Sem texto não há normas; não há normas sem textos.

Em síntese: não há um lado "b" da Constituição a ser "descoberto" axiologicamente, como se "por debaixo do texto da Constituição existissem valores a serem desvelados pela cognição do intérprete". A resposta adequada para o caso da união estável (homoafetiva) depende de alteração legal-constitucional. Veja-se, v.g., o caso espanhol, em que o problema foi resolvido mediante a edição de lei. Na terra de Cervantes, o Poder Judiciário não se sentiu autorizado a "colmatar" a "inconstitucionalidade da Constituição".

\section{De Como A Postura Hermenêutica Aqui Defendida Não Pode Ser Confundida Com} Algum Tipo De Interpretativismo. 
E não se diga - como soe acontecer quando se defende a Constituição e a preservação dos mecanismos democráticos de sua alteração contra as preferências individuais - que isso seria uma espécie de "interpretação literal" da Constituição, ou "interpretação restritiva" ou, ainda, uma espécie de interpretativismo. Esse é o caso de Eduardo Appio (cf. APPIO, 2009) que não entendeu a tese proposta para combater o problema da discricionariedade no direito. Ora, dizer que o julgador não possui discricionariedade no momento decisório está muito longe de ser uma defesa de um interpretativismo constitucional. Aliás, nos parece claro que há, neste caso, uma articulação equivocada do conceito de interpretativismo. Como é cediço, interpretativistas são as posturas teóricas que defendem uma interpretação originalista da Constituição. Na medida em que tais teorias surgem nos Estados Unidos, trata-se de um originizalismo com relação à Constituição Norte-americana. Sendo mais claro, há uma disputa histórica entre os teóricos norte-americanos - pelo menos desde o clássico artigo de Thomas Grey, que, pela primeira vez, estabeleceu e classificou desse modo a diferença metodológica em relação à interpretação da Constituição (cf. GREY, 1975, pp. 703 e segs.) - sobre como deve ser encarada, metodicamente, a interpretação da Constituição. Segundo Grey, duas são as posições que se contrapõem: o interpretativismo e o não-interpretativismo. $\mathrm{O}$ interpretativismo relaciona-se à postura origininalista segundo a qual os limites de liberdade de conformação do legislador devem ser mantidos dentro daquilo que foi "querido" pelos pais fundadores dos Estados Unidos no momento da consagração da Constituição; ou seja, trata-se de uma espécie de psicologismo hermenêutico, similar às posturas subjetivistas que defenden ser o telos da interpretação jurídica a identificação da vontade do legislador (voluntas legislatoris). Veja-se, portanto, que isso nada tem haver com interpretação literal do texto da Constituição ou com uma interpretação constitucional de cunho "restritivo". Já as posturas não-interpretativistas postulam uma espécie de política constitucional, aproximando-se das idéias defendidas pelo realismo jurídico (STRECK, 2009, p. 458).

Ora, por certo que, ao defendermos a possibilidade e a necessidade de respostas corretas em direito (cf. STRECK, 2009), não é possível nos rotular como interpretativistas (originalistas). Isso por um motivo simples: quando afirmamos tal tese - de que a resposta adequada à Constituição, no caso vertente, passa pelos meios democráticos de decisão (o que, por exemplo, Habermas diria disso?) -, temos por pressuposto que a dicotomia interpretacionismo/não-interpretacionismo está - de há muito - superada e os problemas daí decorrentes já tenham sido sanados. Isto porque, quando em Law's Empire Ronald Dworkin enfrenta o aguilhão semântico e o problema do pragmatismo, há uma inevitável superação das teses clássicas sobre a interpretação da Constituição Americana. 
Ou seja, o problema da resposta adequada à Constituição - e não a um conjunto de valores (sic) que ninguém sabe bem o que é -, não se resume à identificação da sentença judicial com o texto da lei ou da Constituição. Se pensássemos assim, estaríamos ainda presos aos dilemas das posturas semânticas. Quando se fala nesse assunto há uma série de acontecimentos que atravessam o direito que ultrapassam o mero problema da "literalidade do texto".

Por isso, é preciso evitar a seguinte confusão: quando asseveramos que os limites semânticos do texto devem ser respeitados (minimamente), como no caso do problema envolvendo a união de pessoas do mesmo sexo, não se pode concluir de nossa abordagem um inexplicável viés de contenção judicial em benefício de uma estrita exegese, de acordo com a literalidade da norma. Longe disso! Não é possível imaginar que estamos aqui a pregar uma modalidade de laissez-faire hermenêutico. É preciso insistir: dizer que o sentido não está à disposição do intérprete é diferente de dizer que há uma "exegese de estrita literalidade".

\section{5. À Guisa De Considerações Finais}

Como nota final - e que isso fique bem claro - voltamos a lembrar que não somos contrários à regulamentação da união homoafetiva. Desde já, colocamo-nos à disposição para a discussão no plano da elaboração legislativa (por lei ou por emenda constitucional). Entendemos, tal qual entende a Procuradoria Geral da República, que a regulamentação é necessária para proteção dos direitos pessoais e patrimoniais dos homossexuais que vivem como consortes. Porém, pelos motivos amplamente expostos acima, estamos convictos que não é através do exercício de um ativismo judicial que essa regulamentação deve ser levada a efeito. Em nome do direito não podemos fragilizar o direito. Não se pode confundir a jurisdição constitucional, absolutamente necessária para concretizar direitos previstos na Constituição, com um apelo indevido à jurisdição para que atue nas hipóteses que não estão previstas na Constituição (aliás, no caso, a Constituição aponta para outro sentido).

Temos uma Constituição que é o Alfa e o Ômega da ordem jurídica democrática. Uma Constituição dirigente e compromissória. Viver em uma democracia tem seus custos. Neste caso um custo básico: os pré-compromissos constitucionais só podem ser liberados por aqueles que a própria Constituição determina (o poder constituinte derivado). Se tudo o que não está previsto na Constituição pode ser "realizado" pelo Poder Judiciário, não precisaríamos sequer ter feito a Constituição: o Judiciário faria melhor (ou o Ministério Público!). A propósito: se a tese da referida ADPF vingar, há uma série de reivindicações que 
devem desde já ser encaminhadas ao Poder Judiciário (e que possuem amplo apoio popular...!). Precisamos enumerá-las?

Em suma: propugnando sempre pela preservação do grau de autonomia atingido pelo direito e na democracia, pensamos que melhor mesmo é confiar na Constituição e na forma que ela mesma impõe para a sua alteração e à formulação de leis. Afinal, duzentos anos de constitucionalismo deveria nos ensinar o preço da regra contramajoritária. Ulisses no comando do seu barco sabia do perigo do canto das sereias...! Ah, os fatos sociais...; nada mais, nada menos, que o retorno ao velho positivismo fático; enfim, em pleno Estado Democrático de Direito, a volta ao velho "realismo jurídico".

E, numa palavra final: quando a Constituição não diz o que gente quer, não dá "alterála" ou "esticá-la" a partir de princípios construídos ad hoc. Não se altera a Constituição por intermédio de ativismos judiciais. Quem sabe deixemos isso ao parlamento? Ou isso, ou entreguemos tudo às demandas judiciais! Mas, depois, não nos queixemos do "excesso de judicialização" ou de “ativismos”...! Isso, as vezes, é "bom”; e, as vezes é “ruim”...!

\section{REFERÊNCIAS BIBLIOGRÁFICAS}

APPIO, Eduardo. Direitos das minorias. São Paulo: Revista dos Tribunais, 2009.

BACHOF, Otto. Normas constitucionais inconstitucionais?. 1 ed. Coimbra: Almedina, 1994. Estado de Direito e Poder Político. Boletim da Faculdade de Direito de Coimbra, vol. LVI, Coimbra, 1996.

BARRETO, Vicente de Paulo. Da interpretação à hermenêutica constitucional. In: Margarida Lacombe (org.). 1988-1998: uma década de Constituição. Rio de Janeiro: Renovar, 1999.

Dicionário de Filosofia do Direito. São Leopoldo/Rio de Janeiro: Unisinos/Renovar, 2005 .

DWORKIN, Ronald. Direito de Liberdade. Leitura Moral da Constituição Americana. São Paulo: Martins Fontes, 2006a.

A Virtude Soberana. São Paulo: Martins Fontes, 2006 b.

Levando os Direitos a Sério. São Paulo: Martins Fontes, 2002.

GREY, Thomas C. "Do We Have un Unwritten Constitution?” In: Stanford Law Review, n. 27, 1975.

HABERMAS, Jürgen. Direito e democracia I e II. Rio de Janeiro: Tempo Brasileiro, 1997. Consciência Moral e Agir Comunicativo. Rio de Janeiro: Tempo Brasileiro, 1989. 
LAMEGO, José. Hermenêutica e Jurisprudência. Análise de uma Recepção. Lisboa: Fragmentos, 1990.

LARENZ, Karl. Metodologia da Ciência do Direito. Tradução de José Lamego. 3 ed. Lisboa: Calouste Gulbenkian, 1997.

OLIVEIRA, Rafael Tomaz de. Decisão Judicial e o Conceito de Princípio. A hermenêutica e a (in)determinação do dirieto. Porto Alegre: Livraria do Advogado, 2008.

STEIN, Ernildo. Exercícios de fenomenologia. Limites de um paradigma. Ijuí: Unijuí, 2004. Aproximações sobre hermenêutica. 2 ed. Porto Alegre: Edipucrs, 2004.

STRECK, Lenio Luiz. Verdade e Consenso. Constituição, Hermenêutica e Teorias discursivas: da possibilidade è necessidade de respostas corretas em Direito. 3 ed. Rio de Janeiro: lumen Juris, 2009.

Hermenêutica Jurídica e(m) Crise. Uma exploração hermenêutica da construção do Direito. 8 ed. Porto Alegre: Livraria do Advogado, 2008.

Jurisdição Constitucional e Hermenêutica - Uma Nova Crítica do Direito. 2a ed. Rio de Janeiro: Forense, 2004.

WOLFE, Christopher. The rise of modern Judicial Review. From constitutional interpretation to jugde-made law. Nova York: Rowman \& Littefieleld, 1994. 